\title{
The Effects of Adiponectin and Leptin on Human Endothelial Cell Proliferation: A Live-Cell Study
}

\author{
Granada Álvarez $^{\mathrm{b}}$ M. Visitación Bartoloméd ${ }^{\mathrm{d}}$ María Miana ${ }^{\mathrm{a}}$ \\ Raquel Jurado-López ${ }^{\text {a }}$ Ruben Martín ${ }^{\text {e,f }}$ Pilar Zuluaga ${ }^{c}$ \\ Ernesto Martinez-Martinez $^{a} \quad$ M. Luisa Nieto ${ }^{\text {e }}$ Luis A. Alvarez-Sala $^{b}$ \\ Jesús Millán ${ }^{b}$ Vicente Lahera ${ }^{a}$ Victoria Cachofeiro ${ }^{a}$ \\ Departments of a Physiology, ${ }^{b}$ Medicine (Hospital Gregorio Marañón) and 'Statistics and Operations Research, \\ School of Medicine, and d Department of Ophthalmology and Oto-Rhino-Laringology, School of Psychology, \\ Universidad Complutense de Madrid, Madrid, ${ }^{e}$ Institute of Molecular Biology and Genetics (CSIC-UVa), and \\ f ICICOR, Hospital Clínico, Valladolid, Spain
}

\section{Key Words}

Adiponectin • Leptin • Endothelial cells • Proliferation •

Live-cell image technique

\begin{abstract}
The effect of adiponectin and leptin on the proliferation of the human microvascular endothelial cell line (HMEC-1) was studied in the absence or presence of fetal bovine serum (FBS). The participation of extracellular signal-regulated kinase (ERK) and phosphatidylinositol 3-kinase/Akt (PI-3K/Akt) pathways in this effect were evaluated. We studied the effect of both adipokines on the motility, mitosis, proliferation and cell death processes of HMEC-1 cells using live-cell imaging techniques. Adiponectin but not leptin further increased the proliferative effect induced by FBS on HMEC-1. This effect seems to be the consequence of an increase in the mitotic index in adiponectin-treated cells when compared to untreated ones. The presence of either the mitogen-activated protein kinase (MAPK) inhibitor (PD98059), or PI-3K inhibitor (LY294002), reduced the effect of adiponectin in a dose-de-
\end{abstract}

\section{KARGER}

Fax +41613061234 E-Mail karger@karger.ch www.karger.com
(C) 2012 S. Karger AG, Basel

$1018-1172 / 12 / 0492-0111 \$ 38.00 / 0$

Accessible online at:

www.karger.com/jvr pendent manner. Neither adipokine was able to affect HMEC1 proliferation in FBS-free conditions. Duration of mitosis, cell motility and the cell death process were similar in all conditions. These data suggest that adiponectin and leptin exert different effects on endothelial cell function. Adiponectin was able to potentiate proliferation of HMEC-1. This effect involves the activation of both PI3-K/Akt and ERK/MAPK pathways. However, it seems to exert minimal effects on HMEC-1 function in the case of leptin.

Copyright $\odot 2012$ S. Karger AG, Basel

\section{Introduction}

The incidence of obesity has increased to epidemic proportions in recent years. Regrettably, this increase has not only affected the adult population, but it has also be-

\section{G.Á. and M.V.B. contributed equally to this study.}

Dr. Victoria Cachofeiro

Departamento de Fisiología, Facultad de Medicina, Universidad Complutense

Av. de la Complutense s/n

ES-28040 Madrid (Spain)

Tel. +34 1394 1489, E-Mail vcara@med.ucm.es 
come highly prevalent in children and teenagers $[1,2]$. Obesity has become a major health, social and economic problem of global significance. The effects of excess weight have been associated with a range of medical problems, including high cardiovascular morbidity and mortality [3]. Several factors have been suggested as important players in the cardiovascular risk associated with a high body weight, including resistance to insulin, hypertension, dyslipemia and inflammation [4]. Some data have also suggested the increase in adipose tissue observed in obese individuals to be an important contributor to these alterations [5]. In support of this affirmation is that, in subjects with severe coronary disease who already show endothelial dysfunction $[6,7]$, the presence of abdominal obesity further worsens vascular function, lowers endothelium-dependent relaxation and a higher response to angiotensin-II is observed. These alterations occur independently of other cardiovascular risk factors such as insulin resistance and levels of inflammatory markers [8].

Adipose tissue is not simply an energy store. Some studies have also demonstrated it to be a highly complex endocrine organ capable of synthesizing a great variety of factors with important local and systemic effects $[9,10]$. Circulating levels of these factors, known as adipokines, become modified with body weight changes. In obesity, due to increased production, most adipokine levels are high. In contrast, adiponectin production is reduced and seems to be an exception $[11,12]$. Adiponectin is an important regulator of lipid and glucose metabolism that circulates under normal conditions in high levels (range $2-20 \mu \mathrm{g} / \mathrm{ml}$ ) as several oligomeric forms [13, 14]. Plasma levels of adiponectin are reduced in the presence of different cardiovascular risk factors, including dyslipemia, hypertension and diabetes $[13,15]$. Some data have suggested that high levels of circulating adiponectin reduce the risk of coronary heart disease in type 2 diabetes patients and are associated with a reduced risk of myocardial infarction in apparently healthy subjects. Therefore, hypoadiponectinemia has been considered to be a marker of coronary artery disease [15]. This could be explained by the fact that adiponectin can exert a protective role in the vascular wall through nitric oxide production $[16,17]$. Some studies have also suggested additional effects, such as antioxidant and anti-inflammatory as well as the inhibition of smooth cell proliferation and migration $[18,19]$. These actions are mediated by binding 2 seven-transmembrane receptors: adiponectin receptor (AdipoR) 1 and 2 [20].
Leptin, mainly produced in adipose tissue, plays a key role in the regulation of food intake, energy balance and glucose homeostasis [10]. It circulates under normal conditions in the range of $1-15 \mathrm{ng} / \mathrm{ml}$. In obese subjects, however, leptin levels increase in proportion to their body weight [21]. This has been explained by a hypothalamus resistance to leptin and, in consequence, an inability to adequately control appetite pathways [22]. However, this resistance seems to not equally affect all leptin target tissues, since the heart and vascular wall are unaffected [22]. In these conditions, high leptin levels can exert deleterious effects on vascular function, since hyperleptinemia is associated with altered nitric oxide activation, oxidative stress, inflammation and changes in vascular smooth muscle cell activity $[22,23]$. While it is accepted that leptin can be deleterious to vascular function and adiponectin can be protective [24,25], their respective specific actions on endothelial cell function (e.g. proliferation, mitosis, motility and death) are not well established because there is little information available and many results tend to be contradictory.

In vitro live-cell technique permits the observation and direct filming of different cell-life processes such as mitosis, proliferation, motility and senescence. This technique is a valuable tool in the study of dynamic events that occur over a period of many minutes, hours or days, i.e. time scales that do not readily lend themselves to being recorded with full-motion video. Instead, capturing sequential images at distinctly spaced time intervals followed by playback in real time can often permit the observation of relatively slow events on a much faster time scale and reveal important results.

The aim of this study was to analyze the effect of adiponectin and leptin on the in vitro proliferation of the human microvascular endothelial cell line (HMEC-1). We also evaluated the role of 2 classic cell proliferation pathways, the extracellular signal-regulated kinase (ERK)/mitogen-activated protein kinase (MAPK) pathway [26] and phosphatidylinositol 3-kinase/Akt (PI-3K/Akt) [27] in the effects of both adipokines on HMEC-1 proliferation. In addition, we used live-cell techniques to study the effects of adiponectin and leptin on the motility, mitosis, proliferation and death processes of HMEC-1 cells.

\section{Methods}

Materials

We obtained the HMEC-1 from American Type Culture Collection (Manassas, Va., USA). MCDB 131 medium, fetal bovine serum (FBS), glutamine and penicillin/streptomycin were pur- 
chased from Gibco, Invitrogen, (Grand Island, N.Y., USA). Epithelial growth factor (EGF) was obtained from Upstate Biotechnology (Lake Placid, N.Y., USA). We purchased adiponectin (fulllength form) and leptin from Biovendor GmbH (Heidelberg, Germany). Trypsin-EDTA, hydrocortisone, PD 98059, LY294002 and 5-bromo-2'-deoxyuridine (BrdU) were obtained from Sigma (St. Louis, Mo., USA). BrdU-antibody was purchased from eBioscience (San Diego, Calif., USA). Rabbit phospho-ERK1/2 (Thr202/Tyr204), and phospho-Akt (Ser473) were from Cell Signaling Technology (Boston, Mass., USA). Rabbit anti-human Akt antibody was from Santa Cruz Biotechnology Inc (Santa Cruz, Calif., USA).

\section{Cell Culture Conditions}

We maintained the cells in medium MCDB 131 supplemented with $10 \% \mathrm{FBS}, 10 \mathrm{mM}$ L-glutamine, $100 \mathrm{U} / \mathrm{ml}$ penicillin/streptomycin, $10 \mathrm{ng} / \mathrm{ml} \mathrm{EGF}$ and $1 \mu \mathrm{g} / \mathrm{ml}$ hydrocortisone. The cells were seeded at a density of $1.4 \times 10^{6}$ cells in a T-175 tissue culture flask and then grown as monolayer culture. Cells were passaged with $0.25 \%$ trypsin in $0.01 \%$ EDTA whenever they became confluent. We used cells at a maximum of 5-10 passages. All assays were conducted at temperatures of $37^{\circ} \mathrm{C}$, with $95 \%$ sterile air and $5 \%$ $\mathrm{CO}_{2}$ in a saturation-humidified incubator.

\section{Cell Proliferation Assay}

Cell proliferation was assessed using the CellTiter 96 Nonradioactive Cell Proliferation Assay (Promega Corporation, Madison, Wisc., USA). HMEC-1 cells were grown on 96-well plates $\left(20 \times 10^{3}\right.$ cells/well $)$ in medium with $10 \%$ FBS and were allowed to attach to the well for 24-36 h. Afterwards, cells were starved in FBS-free medium overnight. We performed the following assays: HMEC-1 cells were cultured in medium for $24 \mathrm{~h}$ in the presence or absence of (1) 10\% FBS (controls), (2) with human adiponectin (1-20 $\mu \mathrm{g} / \mathrm{ml})$ and (3) with human leptin (1-100 ng/ $\mathrm{ml})$.

In order to evaluate the participation of the PI-3K/Akt pathway in the effect of adiponectin and leptin on HMEC-1 proliferation, we performed the following assays: HMEC-1 cells were cultured in medium for $24 \mathrm{~h}$ in the presence of (1) the specific PI-3K inhibitor (LY294002, 5-20 $\mu \mathrm{M}$ ) with or without 10\% FBS for $24 \mathrm{~h}$, (2) human adiponectin $(10 \mu \mathrm{g} / \mathrm{ml})$ with LY294002 (5-20 $\mu \mathrm{M})$ and (3) human leptin $(10 \mathrm{ng} / \mathrm{ml})$ with LY294002 (5-20 $\mu \mathrm{M})$.

In order to evaluate the participation of the Ras/ERK pathway in the effect of adiponectin and leptin on HMEC-1 proliferation, the following assays were performed: HMEC-1 cells were cultured in the medium for $24 \mathrm{~h}$ in the presence of (1) the specific MAPK inhibitor PD $98059(5-50 \mu \mathrm{M})$ with or without 10\% FBS, (2) human adiponectin $(10 \mu \mathrm{g} / \mathrm{ml})$ with PD $98059(5-50 \mu \mathrm{M})$ and (3) human leptin $(10 \mathrm{ng} / \mathrm{ml})$ with PD $98059(5-50 \mu \mathrm{M})$.

The proliferative response was quantified by adding MTS tetrazolium solution $(20 \mu \mathrm{l} /$ well). We measured the conversion of MTS tetrazolium to formazan at $490 \mathrm{~nm}$ in a microplate reader (ASYS Hitech GmbH, Austria) after $2-3$ h of incubation. The background readings in the wells with each conditioned medium (with or without FBS) were subtracted from the sample well readouts. The absorbance is directly proportional to the number of living cells in culture. Inhibition of cell proliferation was com-

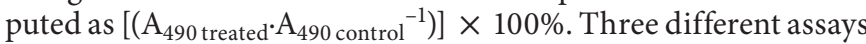
were each performed in quintuplicate.

Adiponectin and Leptin and Endothelial Cell Function
Cell proliferation was also evaluated through the incorporation of BrdU in cells by immunologic staining with the avidin biotin complex technique. HMEC-1 cells were grown in medium with $10 \%$ FBS. Afterwards, they were starved in FBS-free medium overnight and then the following assays were performed: they were cultured in medium for 24 or $48 \mathrm{~h}$ in the presence of (1) $10 \%$ FBS (controls) and (2) FBS with human adiponectin $(5-20 \mu \mathrm{g} / \mathrm{ml})$. $\operatorname{BrdU}(10 \mu \mathrm{M})$ was added to the cultures in the last $24 \mathrm{~h}$ before cells were fixed. We used a monoclonal anti-mouse BrdU-antibody to detect the presence of BrdU in the daughter cells. The assay was performed in quintuplicate.

Negative controls were carried out in the same in vitro conditions, omitting the BrdU in the culture medium.

\section{Immunoblotting of Akt and ERK}

In order to evaluate whether or not adiponectin is able to activate both the PI-3K/Akt pathway and the Ras/ERK pathway in HMEC-1, the following assay was performed: HMEC-1 cells were grown in medium with $10 \%$ FBS. Afterwards, they were starved in FBS-free medium overnight, and then cultured in medium with $10 \%$ FBS. They were harvested at $0,15,30$ and 60 min after the addition of adiponectin $(10 \mu \mathrm{g} / \mathrm{ml})$.

We separated proteins from total cell lysates by SDS-PAGE on $10 \%$ polyacrylamide gels and then transferred to polyvinylidene difluoride membranes (Hybond-P; Amersham Biosciences, Piscataway, N.J., USA). Membranes were probed with the indicated primary antibody followed by incubation with an HRP-linked secondary antibody. Signals were detected using the ECL system (Amersham Biosciences).

\section{Gene Expression of Adiponectin and Leptin Receptors}

Total RNA extraction was isolated from HMEC-1 using RNeasy $^{\mathrm{TM}}$ (Qiagen). RNA was quantified by measurement of optical density at $260 \mathrm{~nm}$ with a Biophotometer (Eppendorf, Germany). RNAs were frozen at $-80^{\circ} \mathrm{C}$ until their use. One microgram of RNA was taken to perform reverse transcription as previously described [28]. Real-time polymerase chain reaction was performed using a fluorescence temperature cycler (SmartCycler; Cepheid, Sunnyvale, Calif., USA). Gene expression was quantified using TaqMan ${ }^{\mathrm{TM}}$ probes and primers for leptin receptor and $18 \mathrm{~S}$ (Roche) and adiponectin receptor types 1 and 2 (Applied Biosystems) as previously reported [28]. The $2^{-\Delta \Delta C T}$ method was used in order to analyze relative changes in gene expression from realtime quantitative PCR experiments [29]. Data were normalized by $18 \mathrm{~S}$ levels and expressed as a percentage of relative expression versus controls (treated-vehicle HMEC-1).

\section{Time-Lapse Cinemicrography}

Live-cell imaging techniques were used in order to evaluate HMEC-1 mitosis, speed motility and cell death processes. The HMEC-1 cells were grown in T-25 flasks (5 to $6 \times 10^{4}$ cells) as monolayer culture in medium with $10 \%$ FBS in the absence or presence of adiponectin $(10 \mu \mathrm{g} / \mathrm{ml})$ or leptin $(10 \mathrm{ng} / \mathrm{ml})$ for 7 days. Culture medium was changed every 3 days.

Images were visualized with a $\times 10$ Nikon optical objective and sequentially captured at $1 \mathrm{image} / \mathrm{min}$ intervals from the same optical field $\left(0.149 \mathrm{~mm}^{2}\right)$ by a Nikon $\mathrm{M}$ inverted microscope (Nikon Corp., Tokyo, Japan). The system was equipped and connected to a JVC KY-F55B color video camera (JVC KY-F55B, JVC Americas Corp, USA) that recorded continuously. 
Fig. 1. Bars represent the effect of adiponectin on HMEC-1 proliferation cultured in either conditioned medium with $10 \%$ FBS (a) or in FBS-free conditions (b). Data are expressed as percentages of controls. Values are mean \pm SEM of 3 different assays performed in quintuplicate. ${ }^{*} \mathrm{p}<0.05$ versus controls (absence of adiponectin).

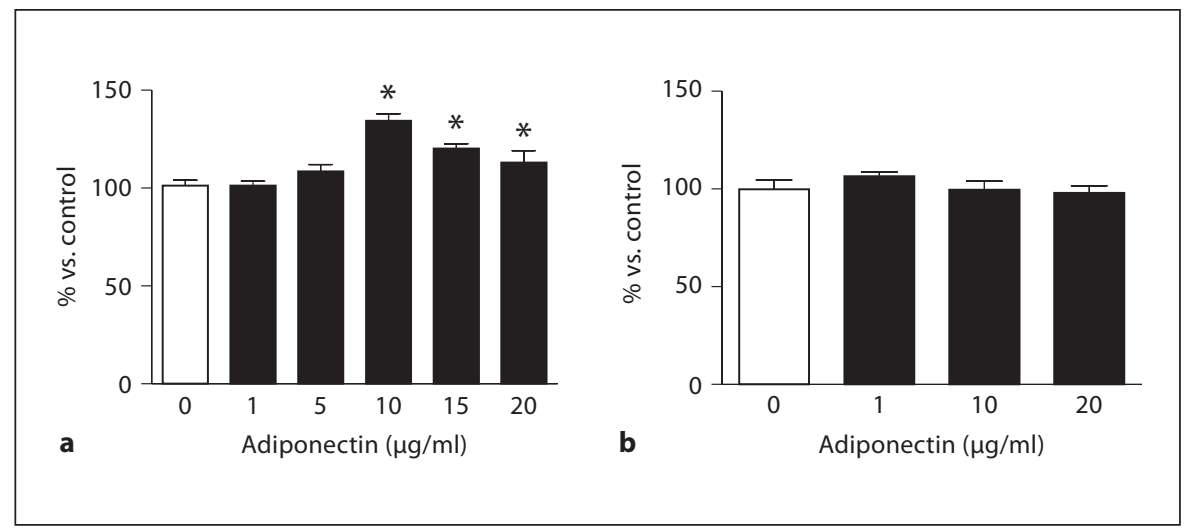

We performed all assays (including Time-Lapse Cinemicrography) in the same in vitro conditions: temperature of $37^{\circ} \mathrm{C}, 95 \%$ sterile air and $5 \% \mathrm{CO}_{2}$ in a saturation-humidified atmosphere. A single researcher who was unaware of the experimental groups performed the analysis.

\section{Cell Mitosis}

In all conditions (control, adiponectin and leptin), the number and time of mitoses were analyzed. Time of mitosis was defined as time elapsed between the cells becoming round and refined until division of the mother cell into two completed separate daughter cells.

Mitotic index was defined as the ratio between the number of cells in mitosis and the total number of cells.

\section{Cell Motility}

Cell motility was evaluated as the ratio of the distance traveled to the travel time between mitoses. We traced the entire trajectory traveled by each cell on a screen; the film was examined and measurements were made. One centimeter of screen corresponded to $9.43 \mu \mathrm{m}$.

\section{Cell Death}

Cells which had detached from the culture surface and showed typical morphological features of cell rounding were considered to be dead. In addition, dead cells showed other morphological features: a nucleus displaced to the periphery and a significant number of vacuoles in the cytoplasm. The cell death rate was calculated as the percentage of dead cells versus the total number of cells.

\section{Statistical Analysis}

Data are expressed as mean \pm SEM. We compared cell proliferation data with 1-factor ANOVA followed by a Newman-Keuls or Dunnet test to assess specific differences among doses or control conditions, respectively, using SPSS 15.0. Live-cell imaging data were compared by a multiple logistic regression model or a 2 -factor ANOVA followed by a Dunnet test using both SPSS 15.0 and Statgraphics 5.1 software. The predetermined significance level was $\alpha=0.05$.

\section{Results}

\section{Cell Proliferation Assay}

Control Cells

The presence of $(10 \%)$ FBS increased $(\mathrm{p}<0.001)$ HMEC-1 proliferation 3.3-fold. Preincubation with the Ras/ERK inhibitor, PD98059, reduced HMEC-1 proliferation in a dose-dependent manner (14 and 20\% at doses of 25 and $50 \mu \mathrm{M}$, respectively; $<<0.01$ ) when compared to control cells (online suppl. fig. S1A; for all online suppl. material, see www.karger.com/doi/10.1159/000332332). Only the high dose $(20 \mu \mathrm{M})$ of PI-3K/Akt inhibitor, LY294002, significantly reduced $(\mathrm{p}<0.05)$ the proliferation of HMEC-1 in conditioned medium by $15 \%$ when compared to control cells (online suppl. fig. S1B) Neither PD98095 nor LY294002 were able to alter HMEC-1 proliferation in FBS-free conditions $(\mathrm{p}=0.213$ and $\mathrm{p}=0.321$, respectively) (online suppl. fig. S2A and S2B).

\section{Effect of Adiponectin}

The presence of adiponectin further potentiated the effect of FBS ( $p<0.0001$ ) on HMEC-1 proliferation, reaching the maximum at a dose of $10 \mu \mathrm{g} / \mathrm{ml}(32 \%, \mathrm{p}<$ 0.01; fig 1a). However, adiponectin was unable to affect ( $p=0.4991$ ) cell proliferation in FBS-free conditions (fig. 1b). We observed a similar pattern in human umbilical vein endothelial cells (HUVEC), since adiponectin was also able to potentiate the effect of FBS on their proliferation ( $p<0.001$, online suppl. fig. S3A) but it did modify cell proliferation in FBS-free conditions $(\mathrm{p}=0.21$; online suppl. fig. S3B), reaching the maximum at the dose of $10 \mu \mathrm{g} / \mathrm{ml}$ (26\%). Similarly, the number of BrdU positive HMEC-1 cells was higher in the presence of adiponectin $10 \mu \mathrm{g} / \mathrm{ml}$ (30\% vs. control cells) (fig. 2a) than at the dose of 5 or $20 \mu \mathrm{g} / \mathrm{ml}$ (15.5 and $22.5 \%$ vs. control, respectively). 
Fig. 2. A positive BrdU expression is present in HMEC-1 cells during the proliferation process in conditioned medium with $10 \%$ FBS. In control (a) and adiponectin $(10 \mu \mathrm{g} / \mathrm{ml})$ (b) conditions, the cell shows an important number of spots in the nucleus of cells (arrowheads).
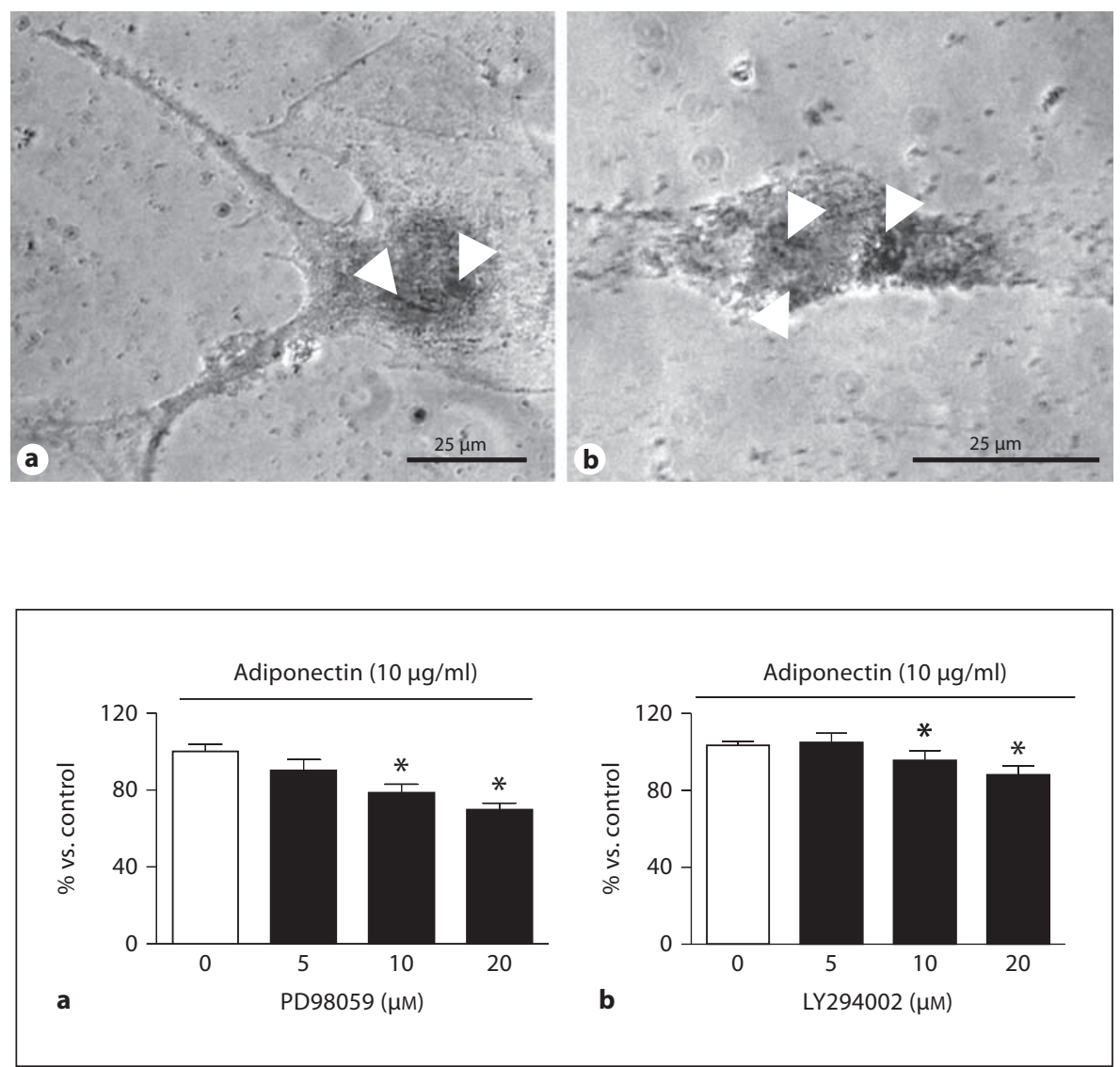

Fig. 3. Bars represent the effect of MAPK inhibitor PD $98059(5-50 \mu \mathrm{M})$ (a) or PI-3K inhibitor LY294002 (5-20 $\mu \mathrm{M})$ (b) on the proliferative action of adiponectin $(10 \mu \mathrm{g} /$ $\mathrm{ml}$ ) cultured in HMEC-1 in conditioned medium with $10 \%$ FBS. Data are expressed as percentages of controls. Values are mean \pm SEM of 3 different assays performed in quintuplicate. ${ }^{*} \mathrm{p}<0.05$ versus controls (absence of inhibitor).
A longer exposure (48 h) to adiponectin did not significantly change this number of BrdU positives cells in the presence of any dose of adiponectin (11.3, 34 and 24\% at the doses of 5, 10 and $20 \mu \mathrm{g} / \mathrm{ml}$ ) A similar percentage of BrdU-positive cells was observed in control conditions at 24 (fig. 2b) or $48 \mathrm{~h}$ (30 and 38\%, respectively). This increase was reduced $(\mathrm{p}<0.0014)$ in a dose-dependent manner in the presence of PD 98059, the Ras/ERK pathway inhibitor (fig. 3a) as compared with cells in the presence of adiponectin $(10 \mu \mathrm{g} / \mathrm{ml})$ alone. Incubation with the PI-3K/Akt inhibitor LY294002, also reduced ( $\mathrm{p}<$ $0.001)$ the effect of adiponectin $(10 \mu \mathrm{g} / \mathrm{ml})$ on HMEC-1 proliferation in a dose-dependent manner (fig. 3b). Adiponectin, at this dose, was able to induce both ERK1/2 (fig. 4a, c) and Akt (fig. 4b, d) phosphorylation, reaching the maximum at 30 and $60 \mathrm{~min}$, respectively.

\section{Effect of Leptin}

Leptin did not affect HMEC-1 proliferation, since preincubation with this factor was unable to modify proliferation independently of the presence $(\mathrm{p}=0.646)$ or not $(\mathrm{p}=0.546)$ of FBS in the medium (fig. 5a, b). We observed a similar pattern with HUVEC (online suppl. fig. S4A and S4B). The presence of either PD98095 or LY294002 was unable to alter the effect of leptin $(10 \mathrm{ng} / \mathrm{ml})$ on HMEC-1 proliferation in medium with $10 \%$ FBS since both inhibitors induced a similar reduction $(\mathrm{p}<0.012$ and $\mathrm{p}<0.03$, respectively) in cell proliferation in the presence or absence of leptin (online suppl. fig. S5A and S5B).

\section{Gene Expression of Adiponectin and Leptin}

Receptors

Adiponectin was not able to modify the gene expression of either of its type 1 and type 2 receptors (fig. 6a, b) or leptin receptors (6C) in HMEC-1. Similarly, the presence of leptin in the incubation media did not modify any of these receptors (fig. $6 \mathrm{a}-\mathrm{c}$ ).

\section{Time-Lapse Cinemicrography}

Control Cells

The mitotic process was similar for all individual HMEC-1 analyzed (fig. 7). The quantification of mitosis 
Fig. 4. Effect of adiponectin $(10 \mu \mathrm{g} / \mathrm{ml})$ on both ERK $1 / 2$ activation (a, c) and Akt (b, d) in HMEC-1 for the time indicated. Representative immunoblots of 4 experiments are shown with antibodies that recognize phosphorylated and total ERK 1/2 or Akt. Values are mean \pm SEM of 4 assays. ${ }^{*} \mathrm{p}<$ 0.05 versus time 0 . Quantification of band intensities was measured by densitometry and normalized to either total ERK1/2 or Akt, respectively.

Fig. 5. Bars represent the effect of leptin on HMEC-1 proliferation cultured in either conditioned medium with 10\% FBS (a) or in FBS-free conditions (b). Data are expressed as percentages of controls. Values are mean \pm SEM of 3 different assays performed in quintuplicate.
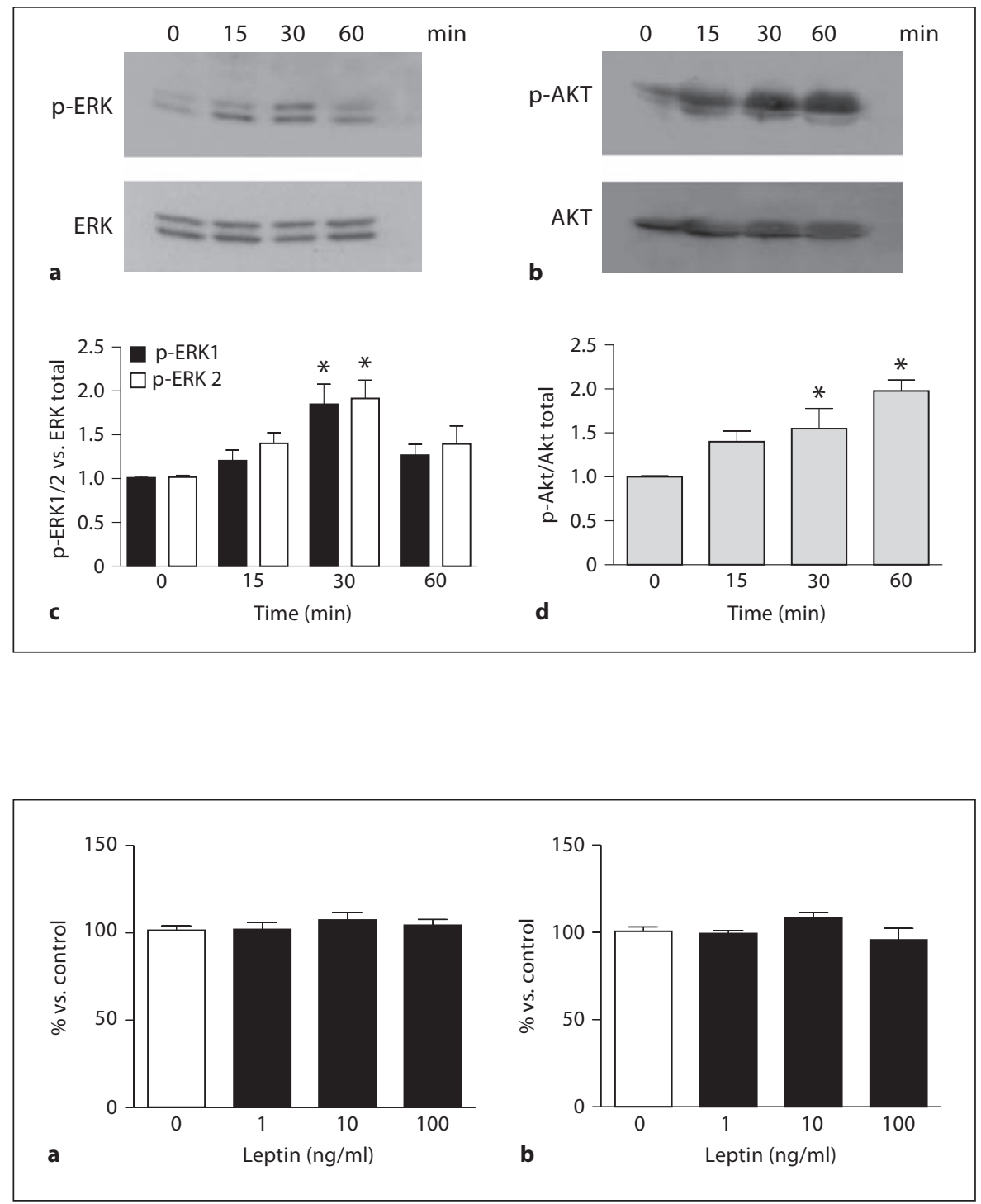
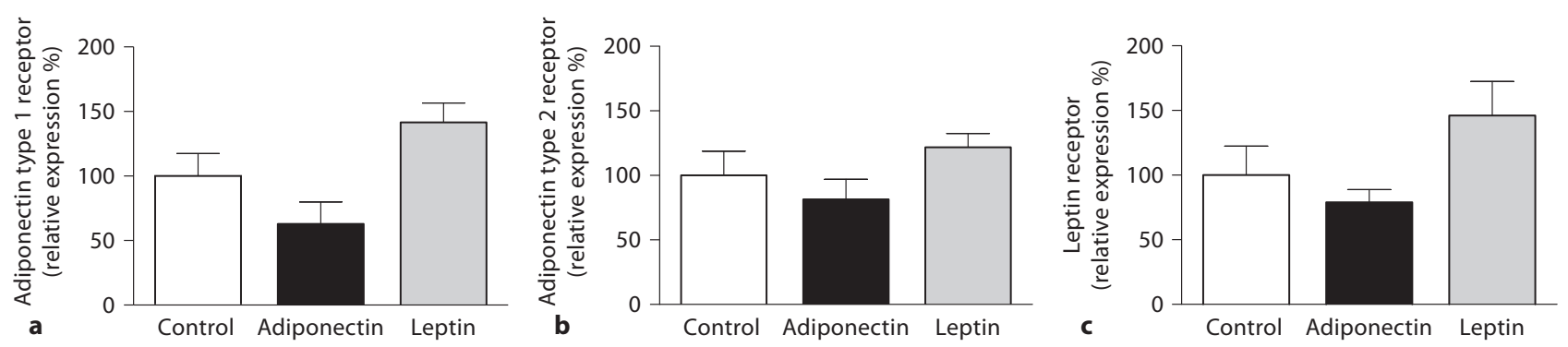

Fig. 6. Bars represent the effect of both adiponectin $(10 \mu \mathrm{g} / \mathrm{ml})$ or leptin $(10 \mathrm{ng} / \mathrm{ml})$ on gene expression of adiponectin receptor type 1 (a), type 2 (b) and leptin (c) in HMEC-1 in conditioned medium with 10\% FBS. Data are expressed as percentages of controls. 18S gene expression was used as a control. Values are mean \pm SEM of 5 different assays. 
duration for each cell was considered from the cells becoming round (fig. 7a) and refined until division of the mother cell into two daughter cells (fig. $7 \mathrm{~b}$ ). The time from the completion of cell division (fig. 7c, d) to the initiation of migration was not considered to fall within the period defining mitosis duration. Mitosis duration was similar throughout the study in control cells $(\mathrm{p}=0.353)$ with the average duration of mitosis being $32.1 \pm 1.4$ $\min$.

Control HMEC-1 observed with time-lapse cinematography is shown in figure 8a-c. Ovoid HMEC-1 cells were observed during the lag phase (or 'period of adaptation' of the cells) in in vitro conditions (fig. 8a). The log phase (cell proliferation period) begins $24-48 \mathrm{~h}$ later (fig. 8b). A majority of cells have started the first mitosis (fig. 8b). Proliferation and growth of cells were observed (fig. 8c). A plateau phase was observed at day 5 and HMEC-1 cells showed a characteristic morphology of endothelial cells (fig. 8c). We observed dead cells on day 6 . Some cells were detached and suspended in the culture media, the average cell death rate being $0.055 \pm 0.011$; no differences were found throughout the study $(\mathrm{p}=0.327)$.

HMEC-1 cells moved in a random manner both amongst themselves and through the flask, with the average cell motility being $31.8 \pm 1.5 \mu \mathrm{m} / \mathrm{h}$; no differences were found throughout the study $(\mathrm{p}=0.728)$.

\section{Adiponectin Stimulation}

The results of HMEC-1 cultured in the presence of adiponectin are shown in figure $8 \mathrm{~d}-\mathrm{f}$. The morphological ovoid form of HMEC-1 cells was maintained during a 24to 36 -hour period (fig. 8d). The lag phase in in vitro conditions (fig. 8d) was similar to that in control conditions (fig. 8a). The HMEC-1 in the presence of adiponectin showed a log phase that started slowly (fig. 8e). A small number of cells began mitosis before $50-72 \mathrm{~h}$ (fig. 8). The number of mitoses increased for 4 days after completion of the lag phase.

The presence of adiponectin increased the number of mitoses in HMEC-1 when compared to control cells, since the number of cells observed at day 4 was higher in adiponectin-treated cells (fig. 8f) than in the control group (fig. 8c). This was confirmed by the fact that the average mitotic index was higher $(\mathrm{p}<0.0001)$ in the presence of adiponectin than in control conditions $(0.44 \pm$ 0.049 vs. $0.33 \pm 0.056$ ). The presence of adiponectin was unable to modify the average duration of mitosis when compared to control conditions $(31.9 \pm 1.6$ vs. $32.1 \pm 1.4$ min, $\mathrm{p}=0.983$; with evolution over time being similar, $\mathrm{p}=0.262)$.

Adiponectin and Leptin and Endothelial Cell Function
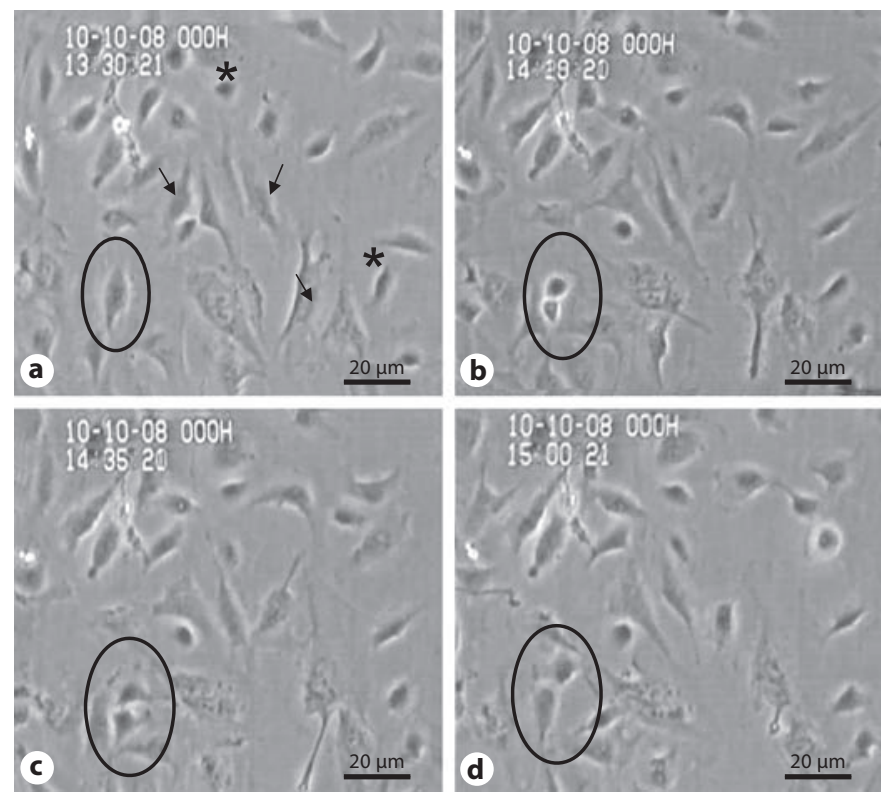

Fig. 7. Mitosis HMEC-1 in time-lapse cinemicrography. a HMEC in log phase. Round (asterisks) or elongated (arrows) cell forms indicate the different live-cell processes. a The mother cell is circled. b Mitosis time is represented by a mother cell changing its morphology and 2 daughter cells are formed (circled). b, c These 2 round cells are completely independent. $\mathbf{d}$ Their size and morphology indicate lack of maturity. Cell motility or migration begins upon completion of mitosis.

A very small number of dead cells were observed in the plates after 6 days in these culture conditions. The presence of adiponectin did not modify $(p=0.132)$ cell death when compared with control cells, with the average cell death rate being $0.062 \pm 0.016$; no differences were observed throughout the study $(\mathrm{p}=0.295)$. Adiponectin was also unable to modify the HMEC-1 speed motility, since the average cell motility was similar to controls $34.6 \pm$ $2.3 \mu \mathrm{m} / \mathrm{h}$ and no differences were found throughout the study $(p=0.224)$.

\section{Leptin Stimulation}

The results of HMEC-1 cultured in the presence of leptin are shown in figure $8 \mathrm{~g}-\mathrm{i}$. The morphological ovoid form of HMEC-1 cells was maintained during the first $24 \mathrm{~h}$ (fig. 8g). The lag phase in in vitro conditions was similar to that in the control (fig. 8a) and adiponectin (fig. 8d) conditions. The duration of mitosis, proliferation and cell death processes of HMEC-1 in the presence of leptin were very similar to the results previously described for control conditions. A majority of cells began

J Vasc Res 2012;49:111-122 


\section{Control}
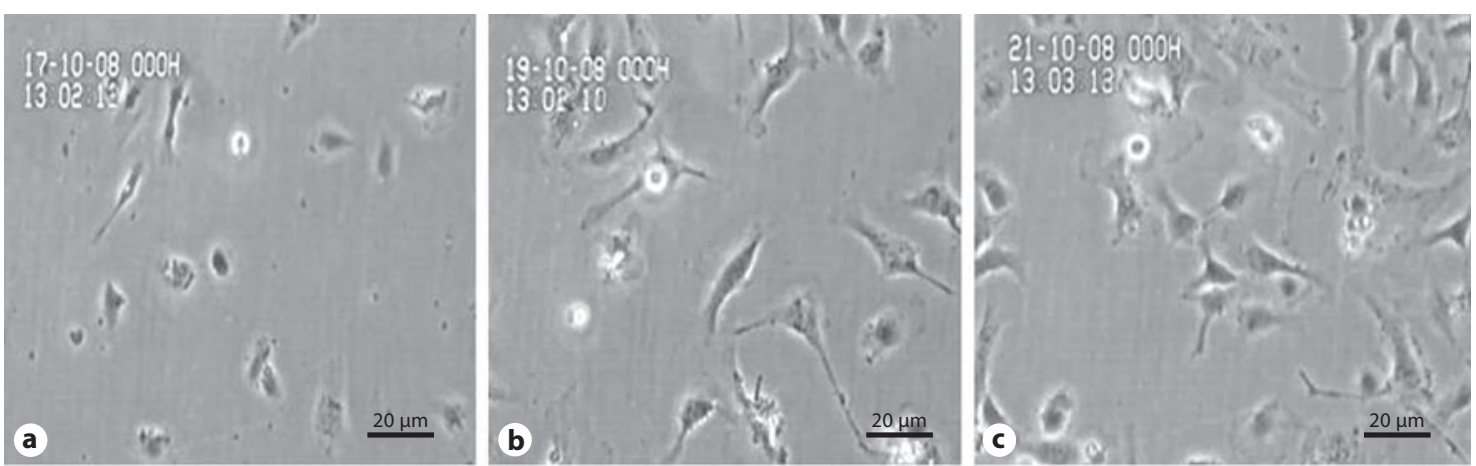

Adiponectin
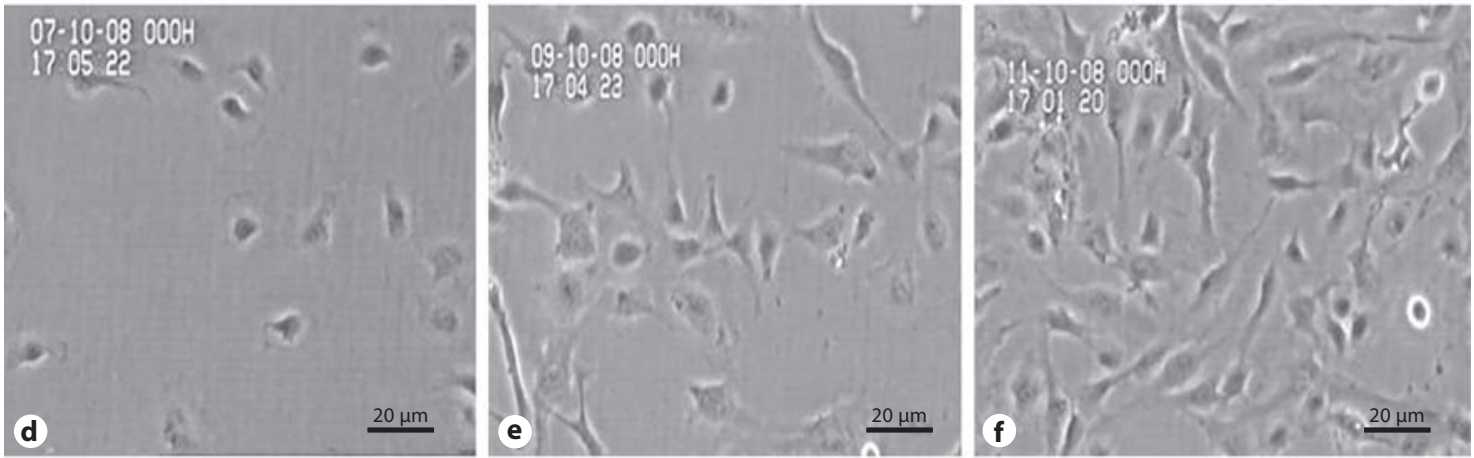

Leptin
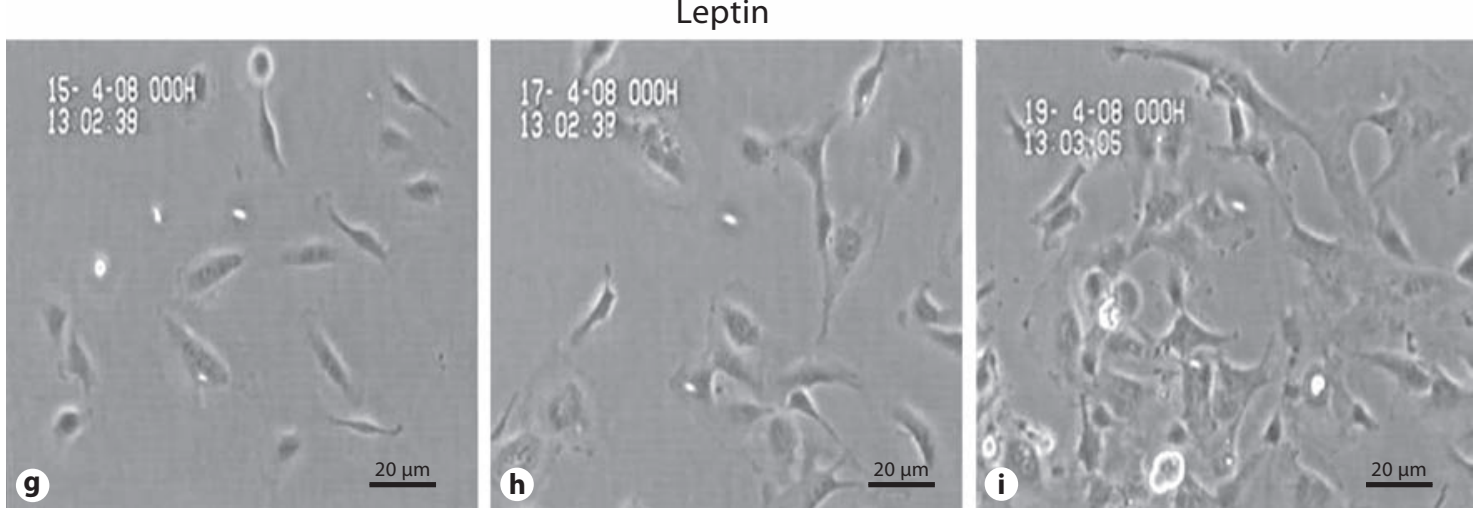

Fig. 8. Photomicrographs obtained in time-lapse cinemicrography. a-c Control HMEC-1. a Lag phase, all ovoid HMEC-1 cells are adapting in in vitro conditions. $\mathbf{b}$ Log phase, cells begin first mitosis. c Cell number increases through proliferation. $\mathbf{d}-\mathbf{f}$ Adiponectin stimulation in HMEC-1. d Lag phase, the ovoid HMEC1 cells are adapting to in vitro conditions. e Log phase, all cells begin first mitosis. $\mathbf{f}$ Number of mitoses is higher and number of cells quickly increases. g-i Leptin stimulation in HMEC-1. g Lag phase, HMEC-1 cells are adapting to in vitro conditions. $\mathbf{h}$ Log phase, all cells begin first mitosis. Number of mitoses is similar to that in control conditions (b). $\mathbf{i}$ The number of cells increases slowly. the first mitosis $24 \mathrm{~h}$ later (fig. $8 \mathrm{~g}$ ). The increase in mitosis continued for $48-72 \mathrm{~h}$ (fig. $8 \mathrm{~h}$ ). The number of mitoses decreased and cells acquired the morphology of mature endothelial cells (plateau phase) (fig. 8i). The presence of leptin was unable to modify the duration of mitosis when compared with controls $(31.1 \pm 1.1$ vs. $32.1 \pm 1.4 \mathrm{~min}$, $\mathrm{p}=0.983)$, this being similar throughout the study ( $\mathrm{p}=$ 0.754). Leptin-treated cells showed a similar mitotic index to the controls $(0.37 \pm 0.06, \mathrm{p}=0.160)$. 
We observed a very small number of dead cells in the plates after 6 days in these culture conditions. The presence of leptin did not modify average cell death rate when compared to control cells $(0.038 \pm 0.012, \mathrm{p}=$ 0.782 ) and this did not change throughout the study $(p=0.269)$. Leptin was also unable to modify the HMEC1 speed motility, since the average cell motility was similar to that of the controls $(28.9 \pm 1.8 \mu \mathrm{m} / \mathrm{h}, \mathrm{p}=0.124)$ and no differences were found throughout the study $(\mathrm{p}=0.156)$.

\section{Discussion}

The data show that adiponectin and leptin have different effects on endothelial cell proliferation in in vitro conditions. Adiponectin favors both HMEC-1 and HUVEC proliferation in the presence of FBS, while leptin is unable to modify it. The effect induced by adiponectin seems to involve an increase in the number of mitoses without affecting the duration, and involves the partial activation of both PI3-K/Akt and ERK/MAPK pathways. Both adipokines, however, were unable to modify the duration of mitosis, cell death rate or cellspeed motility.

HMEC-1 cells proliferate in the presence of FBS (10\%). This proliferation is partially mediated by the activation of both PI3-K/Akt and ERK/MAPK pathways. Adiponectin at physiological doses potentiates proliferation in both HMEC-1 and HUVEC, but it does not modify cell proliferation in cells in FBS-free conditions. These data suggest that adiponectin can favor endothelial cell proliferation, although it is unable to initiate this process. This effect seems to not be shared by other adipokines such as leptin or tumor necrosis factor. This affirmation is based on the fact that leptin seems to not exert any relevant effect on endothelial cell proliferation even at a dose that can be reached in obese subjects, confirming previous studies [30]. Tumor necrosis factor, by contrast, is able to reduce HMEC-1 and HUVEC proliferation in the presence of FBS (online suppl. fig. S6B and S7B). Therefore, it seems that adiponectin exerts a modulatory role in endothelial cell proliferation, facilitating the maintenance of endothelial cell renewal. Similarly, some data have reported that adiponectin is able to induce in vitro angiogenesis, since it stimulates differentiation of HUVEC into capillary-like structures or blood vessel growth in a rabbit corneal model [27]. In addition, adiponectin knockout mice show an impaired angiogenic response to ischemia in their hind limbs that improves after adiponectin ad- ministration [31]. However, a negative modulation has also been reported in bovine or human endothelial cells, in which adiponectin suppresses cell proliferation induced by fibroblast growth factor 2 or oxidized LDL [17, 32]. Various causes can be argued for these discrepant results, including endothelial cell origin (large or microvessel), experimental conditions (stimulated or not) or the cell species utilized. Also contributing to discrepant results could be the actual form of adiponectin utilized in the study - both trimers and hexamers have more biological action than the monomer. The globular form (the proteolytic cleavage product of adiponectin) circulating in human plasma is associated with fewer beneficial effects than the full form (the most common circulating form) $[20,33,34]$. Therefore, it is possible to suggest that adiponectin's final biological effect is affected by the presence (or not) of external factors, with the microenvironment thus being a crucial determinant (via oxidative stress or inflammation) for the expression of the potential effects of adiponectin. Further studies will be needed to identify the precise molecular mechanisms underlying these outcomes. It is important to mention that adiponectin's proliferative effect does not seem to be universal. Rather, it seems to be specific to cell type, as it has been shown that adiponectin inhibits smooth muscle cell proliferation $[18,35]$.

This increase in HMEC-1 proliferation observed in the presence of adiponectin seems to be the consequence of an increase in the number of mitoses induced by this factor because the mitotic index was higher in adiponectin-treated than in untreated cells. As the time duration of mitosis was similar in cells under both conditions, the rise in proliferation induced by adiponectin appears to be the consequence of an increase in the number of cells which enter into division, as suggested by the large number of BrdU-positive cells in adiponectin-treated cells. Although some studies have reported that adiponectin is able to reduce the apoptosis of endothelial cells induced by angiotensin II or FBS-deprivation conditions, as suggested by the reduction of caspase- 3 activity $[36,37]$, we did not observe differences in cell death in the presence or absence of adiponectin, supporting that this factor is unable to affect cell lifetime in normal conditions. Mahadev et al. [38] also found that adiponectin at doses slightly lower than the one $(0.5-3 \mu \mathrm{g} / \mathrm{ml})$ used in this study is unable to induce apoptosis in unstimulated endothelial cells. Similarly, leptin has a minimal effect on the HMEC-1 cell death process. However, higher doses $(10-50 \mathrm{nM})$ of leptin than the one we used are able to reduce apoptosis in different human endothelial cells (um- 
bilical, adult and microvascular) through an upregulation of the apoptosis inhibitor bcl-2 [39].

Activation of different signaling cascades including PI-3K/Akt and ERK/MAPK play a crucial role in endothelial cell proliferation by regulating cell cycle progression through the modulation of numerous targets such as cyclins, cyclin-dependent kinases, and cyclin-dependent kinase inhibitors $[26,27,40]$. It has been shown that Akt kinase activity is induced by a number of factors, including growth factors or cytokines in a PI-3K-dependent manner [41, 42]. We have demonstrated that both PI-3K/ Akt and ERK/MAPK pathways are involved in adiponectin-induced HMEC-1 proliferation. The use of specific inhibitors of these pathways, LY294002 and PD98059, respectively, clearly reduces HMEC-1 proliferation after adiponectin stimulation; this suggests that this adipokine can potentiate the activation of the both pathways induced by FBS in endothelial cells. This activation has been previously reported $[27,43]$. In fact, it has been reported that adiponectin is able to stimulate angiogenesis by promoting cross-talk between Akt signaling and AMP-activated protein kinase. In addition, the ERK/ MAPK pathway can also be involved in other actions of adiponectin, as an increase in ERK1/2 phosphorylation has been implicated in the anti-inflammatory action of adiponectin in endothelial cells [44].

This effect seems not to be the consequence of a regulation in adiponectin receptors since the presence of adiponectin was not associated with changes in either AdipoR1 or AdipoR2. They bind to different forms of adiponectin, the first one to globular adiponectin and AdipoR2 to full-length adiponectin [20]. However, we cannot eliminate other effects, since Kosel et al. [45] have reported that adiponectin reduces the dimerization and internalization of the AdipoR1, which have a role in its function.

Endothelial cell migration is central to the homeostatic processes of the vascular wall, including effective immune response and the repair of injured vessels. This implies cell polarization through reorganization of cellular architecture in response to different stimuli. Considering the data, it seems that adiponectin does not play a major role in this process, suggested by the observation that this factor is unable to modify speed motility in HMEC-1. By contrast, it has been reported that this adipokine is able to reduce endothelial cell migration induced by VEGF $[32,38]$. Moreover, different studies have suggested that adiponectin can act as a chemotactic agent of endothelial cells $[27,28]$. Therefore, it seems that adiponectin can exert a different effect on endothelial cell migration, depending on the conditions. Leptin does not seem to be a major regulator of cell motility in HMEC-1 either, because, as already mentioned for adiponectin, no differences in cell speed are observed between leptin-treated or untreated cells. Similarly, leptin at a low dose is unable to modify endothelial progenitor cell migration in response to a scratch wound [46], although at a high dose it is able to reduce the migration of these cells. However, the specific role of leptin on endothelial cell migration seems unclear because some studies have reported that this factor can act as a chemoattractive factor in endothelial cells $[40,47]$.

\section{Conclusions}

We have observed that adiponectin and leptin can exert differential effects on endothelial cell function. In the case of leptin, it seems to play a neutral role because, at physiological levels, it was unable to modify either proliferation or migration. Moreover, the data does not support a potential deleterious effect of leptin on endothelial cells even at levels observed in obese subjects. By contrast, adiponectin is able to potentiate cell growth in cells in a proliferative state, although it is unable to initiate it. This suggests that this adipokine can exert a vascular beneficial effect by favoring the endothelial cell renewal within the vascular wall. This effect could be one of the mechanisms that can participate in the protective actions reported for this adipokine and maximize the importance of maintaining adiponectin plasma levels in a normal range. In addition, these data could help to explain the beneficial effects exerted by adiponectin on the vascular wall.

\section{Acknowledgements}

We thank Aurora Muñoz and Elena Algarra for their technical assistance. This work was supported by grants from Fondo de Investigaciones Sanitarias (PI09/0871) and Mutua Madrileña (60122009). M.M. and R.J. were paid with a grant from Red Cardiovascular del FIS (RD06/0014/0007). L.A.A.-S., J.M., M.V.B., R.M., M.L.N., V.L. and V.C. are members of the Red Cardiovascular del FIS (RD06/0014/000, RD06/0014/0007 and RD06/0014/0010). 


\section{References}

1 Sabin MA, Shield JP: Childhood obesity. Front Horm Res 2008;36:85-96.

-2 Poirier P, Giles TD, Bray GA, Hong Y, Stern JS, Pi-Sunyer FX, Eckel RH: American Heart Association Scientific Statement on Obesity and Heart Disease from the Obesity Committee of the Council on Nutrition, Physical Activity, and Metabolism. Obesity and cardiovascular disease: pathophysiology, evaluation, and effect of weight loss: a 1997 update. Circulation 2006;113:898-918.

-3 Caterson ID, Hubbard V, Bray GA, Grunstein R, Hansen BC, Hong Y, Labarthe D, Seidell JC, Smith SC Jr: Prevention Conference VII: obesity, a worldwide epidemic related to heart disease and stroke: group III: worldwide comorbidities of obesity. Circulation 2004;110:e476-e483.

-4 Bray GA: Medical consequences of obesity. J Clin Endocrinol Metab 2004;89:2583-2589.

5 Thalmann S, Méier CA: Local adipose tissue depots as cardiovascular risk factors. Cardiovasc Res 2007;75:690-701.

-6 Cai H, Harrison DG: Endothelial dysfunction in cardiovascular diseases: the role of oxidant stress. Circ Res 2000;87:840-844.

7 Heitzer T, Schlinzig T, Krohn K, Meinertz T, Münzel T: Endothelial dysfunction, oxidative stress, and risk of cardiovascular events in patients with coronary artery disease. Circulation 2001;104:2673-2678.

-8 Rueda-Clausen CF, López-Jaramillo P, Luengas C, Oubiña MP, Cachofeiro V, Lahera V: Inflammation but not endothelial dysfunction is associated with the severity of coronary artery disease in dyslipidemic subjects. Mediators Inflamm 2009;2009:469169.

-9 Galic S, Oakhill JS, Steinberg GR: Adipose tissue as an endocrine organ. Mol Cell Endocrinol 2010;316:129-139.

10 Lau DCW, Dhillon B, Yan H, Szmitko PE, Verma S: Adipokines: molecular links between obesity and atherosclerosis. Am J Physiol Heart 2005;288:H2031-H2041.

11 Matsubara M, Maruoka S, Katayose S: Inverse relationship between plasma adiponectin and leptin concentrations in normalweight and obese women. Eur J Endocrinol 2002;147:173-180.

-12 Ryan AS, Berman DM, Nicklas BJ, Sinha M, Gingerich RL, Meneilly GS, Egan JS, Elahi D: Plasma adiponectin and leptin levels, body composition, and glucose utilization in adult women with wide ranges of age and obesity. Diabetes Care 2003;26:2383-2388.

-13 Hotta K, Funahashi T, Arita Y, Takahashi M, Matsuda M, Okamoto Y, Iwahashi H, Kuriyama H, Ouchi N, Maeda K, Nishida M, Kihara S, Sakai N, Nakajima T, Hasegawa K, Muraguchi M, Ohmoto Y, Nakamura T, Yamashita S, Hanafusa T, Matsuzawa Y: Plasma concentrations of a novel, adiposespecific protein, adiponectin, in type 2 diabetic patients. Arterioscler Thromb Vasc Biol 2000;20:1595-1599.
14 Tsao TS, Lodish HF, Fruebis J: ACRP30, a new hormone controlling fat and glucose metabolism. Eur J Pharmacol 2002;440:213221.

15 Im JA, Kim SH, Lee JW, Shim JY, Lee HR, Lee DC: Association between hypoadiponectinemia and cardiovascular risk factors in nonobese healthy adults. Metabolism 2006; 55:1546-1550.

16 Cheng KK, Lam KS, Wang Y, Huang Y, Carling $\mathrm{D}$, Wu D, Wong C, Xu A: Adiponectininduced endothelial nitric oxide synthase activation and nitric oxide production are mediated by APPL1 in endothelial cells. Diabetes 2007;56:1387-1394.

17 Motoshima H, Wu X, Mahadev K, Golstein BJ: Adiponectin suppresses proliferation and superoxide generation and enhances eNOS activity in endothelial cells treated with oxidized LDL. Biochem Biophys Res Commun 2004;315:264-271.

18 Shin JH, Kim JH, Lee WY, Shim JY: The expression of adiponectin receptors and the effects of adiponectin and leptin on airway smooth muscle cells. Yonsei Med J 2008;49: 804-810.

19 Zhu W, Cheng KK, Vanhoutte PM, Lam KS, $\mathrm{Xu} \mathrm{A}$ : Vascular effects of adiponectin: molecular mechanisms and potential therapeutic intervention. Clin Sci (Lond) 2008;114: 361-374.

20 Kadowaki T, Yamauchi T: Adiponectin and adiponectin receptors. Endocr Rev 2005;26: 439-451.

21 Könner AC, Klöckener T, Brüning JC: Control of energy homeostasis by insulin and leptin: targeting the arcuate nucleus and beyond. Physiol Behav 2009;97:632-638.

22 Martin SS, Qasim A, Reilly MP: Leptin resistance: a possible interface of inflammation and metabolism in obesity-related cardiovascular disease. J Am Coll Cardiol 2008;52: 1201-1210.

23 Beltowski J: Leptin and atherosclerosis. Atherosclerosis 2006;189:47-60.

24 Fantuzzi G, Mazzone T: Adipose tissue and atherosclerosis: exploring the connection. Arterioscler Thromb Vasc Biol 2007;27:9961003.

25 Kougias P, Chai H, Lin PH, Yao Q, Lumsden $\mathrm{AB}$, Chen C: Effects of adipocyte-derived cytokines on endothelial functions: implication of vascular disease. J Surg Res 2005;126: 121-129.

26 Anjum R and Blenis J: The RSK family of kinases: emerging roles in cellular signalling. Nat Rev Mol Cell Biol 2008;9:747-758.

-27 Ouchi N, Kobayashi H, Kihara S, Kumada $\mathrm{M}$, Sato K, Inoue T, Funahashi T, Walsh K: Adiponectin stimulates angiogenesis by promoting cross-talk between AMP-activated protein kinase and Akt signaling in endothelial cells. J Biol Chem 2004;279:1304-1309.

-28 Martín-Fernández B, de las Heras N, Miana M, Ballesteros S, Delgado C, Song S, Hintze
T, Cachofeiro V, Lahera V: Structural, functional, and molecular alterations produced by aldosterone plus salt in rat heart: association with enhanced serum and glucocorticoid-regulated kinase-1 expression. J Cardiovasc Pharmacol 2011;57:114-121.

29 Miana M, de Las Heras N, Rodriguez C, Sanz-Rosa D, Martin-Fernandez B, Mezzano S, Lahera V, Martinez-Gonzalez J, Cachofeiro V: Effect of eplerenone on hypertension-associated renal damage in rats: potential role of peroxisome proliferator activated receptor gamma (PPAR- $\gamma$ ). J Physiol Pharmacol 2011;62:87-94

30 Wolk R, Deb A, Caplice NM, Somers VK: Leptin receptor and functional effects of leptin in human endothelial progenitor cells. Atherosclerosis 2005;183:131-139.

- 31 Shibata R, Ouchi N, Kihara S, Sato K, Funahashi T, Walsh K: Adiponectin stimulates angiogenesis in response to tissue ischemia through stimulation of AMP-activated protein kinase signaling. J Biol Chem 2004;279: 28670-28674.

32 Bråkenhielm E, Veitonmäki N, Cao R, Kihara S, Matsuzawa Y, Zhivotocsky B, Funahashi T, Cão Y: Adiponectin-induced antiangiogenesis and antitumor activity involve caspase-mediated endothelial cell apoptosis. Proc Natl Acad Sci USA 2004;101:24762481.

33 Fruebis J, Tsao TS, Javorschi S, Ebbets-Reed D, Erickson MR, Yen FT, Bihain BE, Lodish HF: Proteolytic cleavage product of $30-\mathrm{kDa}$ adipocyte complement-related protein increases fatty acid oxidation in muscle and causes weight loss in mice. Proc Natl Acad Sci USA 2001;98:2005-2010.

34 Tomizawa A, Hattori Y, Kasai K, Nakano Y: Adiponectin induces NF-kappaB activation that leads to suppression of cytokine-induced NF-kappaB activation in vascular endothelial cells: globular adiponectin versus high molecular weight adiponectin. Diab Vasc Dis Res 2008;5:123-127.

35 Matsuda M, Shimomura I, Sata, Arita Y, Nishida M, Maeda N, Kumada M, Okamoto Y, Nagaretani H, Nishizawa H, Kishida K, Komuro R, Ouchi N, Kihara S, Nagai R, Funahashi T, Matsuzawa Y: Role of adiponectin in preventing vascular stenosis: the missing link of adipo-vascular axis. J Biol Chem 2002;277:37487-37491.

- 36 Kobayashi H, Ouchi N, Kihara S, Kobayashi H, Ouchi N, Kihara S, Walsh K, Kumada M, Abe Y, Funahashi T, Matsuzawa Y: Selective suppression of endothelial cell apoptosis by the high molecular weight form of adiponectin. Circ Res 2004;94:e27-e31.

37 Lin LY, Lin CY, Su TC, Liau CS: Angiotensin II-induced apoptosis in human endothelial cells is inhibited by adiponectin through restoration of the association between endothelial nitric oxide synthase and heat shock protein 90. FEBS Lett 2004;574:106-110. 
>38 Mahadev K, Wu X, Donnelly S, Ouedraogo R, Eckhart AD, Goldstein BJ: Adiponectin inhibits vascular endothelial growth factorinduced migration of human coronary artery endothelial cells. Cardiovasc Res 2008; 78:376-384.

-39 Artwohl M, Roden M, Hölzenbein T, Freudenthaler A, Waldhäusl W, Baumgartner-Parzer SM: Modulation by leptin of proliferation and apoptosis in vascular endothelial cells. Int J Obes Relat Metab Disord 2002;26:577580 .

-40 Chen Z, Liu F, Ren Q, Zhao Q, Ren H, Lu S, Zhang L, Han Z: Hemangiopoietin promotes endothelial cell proliferation through PI-3K/ Akt pathway. Cell Physiol Biochem 2008;22: 307-314.
41 Grehan JF, Levay-Young B.K, Fogelson J.L, François-Bogarçon V, Benson BA, Dalmasso AP: IL-4 and IL-13 induce protection of porcine endothelial cells from killing by human complement and from apoptosis through activation of a phosphatidylinositide 3-kinase/ Akt pathway. J Immunol 2005;175:19031910.

42 Kim HH, Shin HS, Kwak HJ, Ahn KY, Kim $\mathrm{JH}$, Lee HJ, Lee MS, Lee ZH, Koh GY: RANKL regulates endothelial cell survival through the phosphatidylinositol 3'-kinase/ Akt signal transduction pathway. FASEB J 2003;17:2163-2165.

43 Lee M, Klein RL, El-Shewy H.M, Luttrell DK, Luttrell LM: The adiponectin receptors adipoR1 and adipoR2 activate ERK1/2 through a Src/Ras-dependent pathway and stimulate cell growth. Biochemistry 2008;47: 11682-11692.
44 Tomizawa A, Hattori Y and Kasai K: Induction of gene expression in response to globular adiponectin in vascular endothelial cells. Life Sci 2009;85:457-461.

45 Kosel D, Heiker JT, Juhl C, Wottawah CM, Blüher M, Mörl K, Beck-Sickinger AG: Dimerization of adiponectin receptor 1 is inhibited by adiponectin. J Cell Sci 2010;123: 1320-1328.

46 Wolk R, Deb A, Caplice NM, Somers VK: Leptin receptor and functional effects of leptin in human endothelial progenitor cells. Atherosclerosis 2005;183:131-139.

47 Chen JX, Stinnett A: Critical role of the NADPH oxidase subunit $\mathrm{p} 47$ phox on vascular TLR expression and neointimal lesion formation in high-fat diet-induced obesity. Lab Invest 2008;88:1316-1328. 